Jurnal Ilmu dan Teknologi Kelautan Tropis, Vol. 9, No. 1, Hlm. 327-336, Juni 2017

\title{
ECONOMIC IMPACT FROM PLASTIC DEBRIS ON SELAYAR ISLAND, SOUTH SULA WESI
}

\section{DAMPAK EKONOMI DARI SAMPAH PLASTIK DI PULAU SELAYAR, SULAWESI SELATAN}

\author{
Roni Hermawan $^{1 *}$, Ario Damar ${ }^{2}$, and Sigid Hariyadi ${ }^{2}$ \\ ${ }^{1}$ Post-graduate Student of Coastal and Marine Resources Management, FPIK-IPB, Bogor \\ *E-mail: rooney_hermawan@yahoo.com \\ ${ }^{2}$ Departement of Aquatic Resources Management, FPIK-IPB, Bogor
}

\begin{abstract}
ABSTRAK
Sampah plastik dalam jumlah besar terdeposit di pesisir Pulau Selayar yang berhadapan langsung dengan Laut Jawa selama musim barat. Sampah plastik telah menimbulkan dampak sosial dan ekonomi bagi nelayan di Pulau Selayar. Penelitian ini bertujuan untuk mengkaji komposisi, kepadatan dan sebaran dari sampah plastik; dampak terhadap sosial dan ekonomi. Metode transek garis digunakan dalam penelitian ini untuk menentukan jumlah dan sebaran sampah plastik. Ukuran sampah plastik yang diamati adalah $>2,5 \mathrm{~cm}$ dikategorikan sebagai sampah makro. Penelitian ini dilaksanakan pada Februari sampai Maret 2016. Dampak sampah plastik menurunkan pendapatan dari pariwisata, industri perikanan, mengganggu operasi penangkapan ikan, memerlukan pembersihan dan perbaikan pada alat langkap. Biaya yang dikeluarkan untuk perbaikan dan pembersihan kapal ikan sekitar 192,9 juta rupiah tiap tahun dan perbaikan alat tangkap 156,2 juta rupiah per tahun. Sampah plastik terdiri dari botol plastik, gelas plastik, tali dan jaring ikan, korek gas, keranjang plastik, pelampung, kemasan plastik, sikat gigi dan alat suntik. Rata-rata sampah plastik adalah 9,5 $\pm 2,7 \mathrm{item} / \mathrm{m}^{2}$ dan berat sekitar $229,2 \pm 109,9 \mathrm{~g} / \mathrm{m}^{2}$.
\end{abstract}

Kata kunci: dampak, manajemen, Pulau Selayar, sampah plastik, sosial-ekonomi

\begin{abstract}
Enormous plastic debris has been stranded on Selayar island shore during the west monsoon due to its position which is directly faced Java sea. Plastic debris had impacted social and economy of Selayar fishermen. The research was aimed to determine the composition, density, and distribution of the plastic debris; it impacts to social and economy. Line transect was used as the research method to quantify the numbers and width of the plastic debris spread. The size of plastic debris that was researched about $>2,5 \mathrm{~cm}$ which categorized as macro litters. The research was conducted in February to March 2016. The impacts of plastic debris were reduce income from tourism, fishing industry, disrupting fishing operations, requiring clean-up, and repairing vessel. Direct costs for repair and clean-up fishing vessels was about 192.9 million rupiahs per year and repair fishing gears was about 156.2 million rupiahs per year. The plastic debris consists of plastic bottle, plastic cup, rope and fish net, gas matches, plastic box, buoy, food packaging, toothbrush and syringe. The average of plastic debris about $9.5 \pm 2.7 \mathrm{item} / \mathrm{m}^{2}$ and weight about $229.2 \pm 109.9 \mathrm{~g} / \mathrm{m}^{2}$.
\end{abstract}

Keyword: impact, management, Selayar Island, plastic debris, socio-economy

\section{INTRODUCTION}

Plastic debris was increased as growing of economy and plastic for support human life as consumptions or other activities. Plastic products increase significant and domination of every market products since 1930 s to 1940 s. World's plastic production reach 288 metric tonnes in 2012 or increase $620 \%$ from 1975 (Jambeck et al., 2015). Plastic industries create new products to follow market trends and showing no signs of slowing (Moore, 2015). Plastic debris came from industry, domestic litter, shipping 
vessel, boatship and another land-based source that drive by river or drainasse to the sea (Derraik, 2002 ; UNEP, 2005; Williams and Simmons, 1997).

Plastic debris has been deposit into ecosystem and degradation to be microplastic and become more dangerous. In the environmental, polymer-based spread everywhere and the impacts of polymer are yet fully understood (Lambert, 2013). The impacts of plastic debris to fishing industry are distrubting fishing vessel, ship propeller, ghost fishing from broken or abandoned fishing gear and repairing fishing vessel that requiring cost (Lee, 2014).

Coastal are a vulnerable area from marine waste, some of the ecosystems depend on coastal and used by many stakeholders (Lindgren, 2011). Plastic debris drive by surface currents, wind-driven mixing, down welling and/or currents act to carry plastic particles (Choy and Drazen, 2013), then end up on the beach and make many environmental problems. West coast of Selayar island is directly facing open sea, on west monsoon (January to April) marine debris drive by surface current from Makassar strait and Java sea to Selayar island west coast (Balitbang KP, 2016; ECMWF, 2016; Wyrtki, 1961). Few researchs about marine plastic debris on Indonesia (Sherman and Sebille, 2016; Uneputty and Evans, 1997; Uneputty and Evans, 1997b; Walalangi, 2007; Willoughby, 1997).

Plastic litter on Selayar island west coast are unmanaged, when east monsoon (April to September) plastic litters debris mostly drive back by tide and surface current, then make another problem to other islands. The research was aimed to determine the types, quantities, and distribution of the plastic debris and its impacts to local socioeconomic.

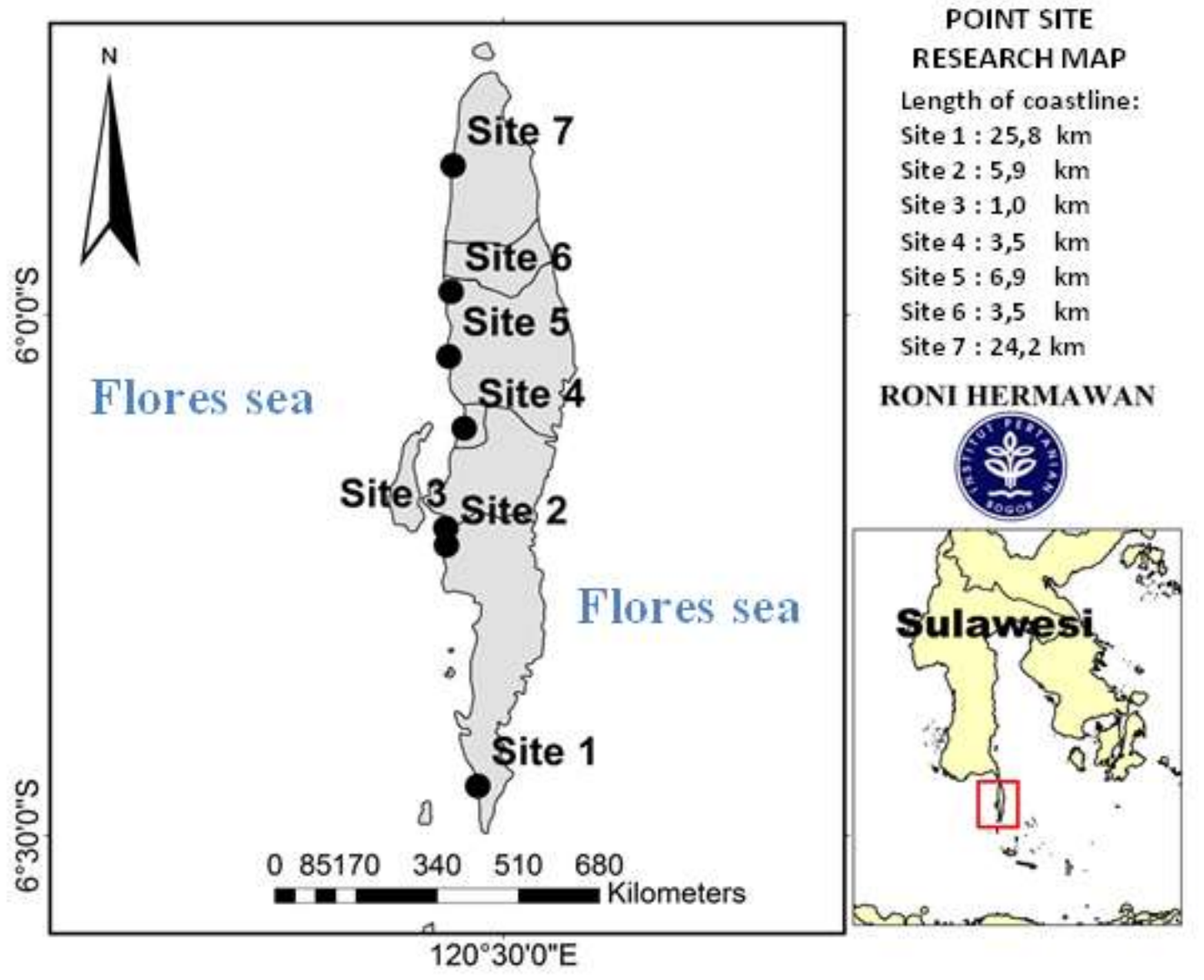

Figure 1. Point site research map. 


\section{METHODS}

\subsection{Time and Location of Reseacrh}

The research was conducted on Selayar Island west coast in February to March 2016, it was the peak of west monsoon to east monsoon transition. The plastic litters was collected from 7 coastline sites depend on coastal landforms where plastic debris was stranded (Figure 1).

\subsection{Methods and Analysis}

Data of plastic debris were collected by line transect method to determine its numbers and spreads. Transects were $5 \mathrm{~m}$ width and length depend on coastline width. Sample sizes were macrodebris $(>2,5 \mathrm{~cm})$, samples sorted by type for identification, measured, weighed $(\mathrm{g})$ and measured the location plot site $\left(\mathrm{m}^{2}\right)$. The plot point of observation was sorted to clean and marked, each station consists of three plots (Lippiatt et al., 2013 and UNEP, 2009). Social economy impact observed by purposive sampling with 110 locals community, nongovernment organization, and local government.

\subsubsection{Plastic Debris Density (Msodified from Lippiatt et al., 2013)}

Data of plastic debris consist of numbers of debris (item), weight ( $\mathrm{g}$ ) and location area $\left(\mathrm{m}^{2}\right)$.

$$
C=\frac{n}{(w \times l)}
$$

Where: $\mathrm{C}=$ Plastic debris density (item $/ \mathrm{m}^{2}$ ); $\mathrm{n}=$ Number of debris (item); $\mathrm{w}=$ Transect width $(\mathrm{m}) ; \mathrm{l}=$ Tranect length $(\mathrm{m})$.

\subsubsection{Loss of Vessel (Modified from Takehama, 1990)}

Datas of vessel were taken from vessel that operating and anchored on Selayar west coast, operated at less than 300 nautical miles or around of Selayar islans and South Sulawesi.
$A=\left((a \cdot b) \cdot N_{1}\right)+\left((a \cdot c) \cdot N_{2}\right)$

Where: $A=$ Loss of vessel (unit); $a=\Sigma$ essel on west coast (unit); $b=$ Frequency of; entangled of vessel propeller (unit); $c=$ Frequency of others repairing/cleaning (unit); $N_{1}=$ Cost of propeller repairing (rupiah); $N_{2}$ $=$ Cost of others repairing/cleaning (rupiah).

\subsubsection{Loss of Fishing Gear (Modified from Takehama, 1990)}

Fishing gear datas were taken from fixed fishing gear such as set net, fixed lift net, boat lift net and fish traps that operated on Selayar west coast.

$B=((p \cdot q) \cdot R)$

Where: $B=$ Loss of fishing gear (rupiah); $p=$ $\Sigma$ fixed fishing gear on west coast (unit); $q=$ Frequency of extra cleaning, fixing net, rame, buoy, anchor, etc (unit); $R=$ Cost of gear repairing and cleaning (rupiah).

\section{RESULT AND DISCUSSION}

\subsection{Types, Quantities and Distribution of Plastic Debris}

Plastic litters consist of plastic bottle, plastic cup, rope and broken fish net, gas matches, plastic box, bouy, wrapper, tooth brush, and syringe (Figure 2 and 3). Most of the plastic litters are plastic for food or dailyneed packaging, cups and bottle plastics are dominant. On site 4 , total density was about 6 item $/ \mathrm{m}^{2}$ for plastic cup, site 7 plastic bottle was about 5 item $/ \mathrm{m}^{2}$, describe on Table 1 .

On Table 3 shown weight $\left(\mathrm{g} / \mathrm{m}^{2}\right)$ of plastic litters, site 1 is highest with weight about $129 \mathrm{~g} / \mathrm{m}^{2}$ for rope and fish-net and $128,9 \mathrm{~g} / \mathrm{m}^{2}$ for plastic bottle. Rope and fishnet were from abandoned or parts of fishing gears. Based on the calculation results and total length of coastline per site (Figure 1), the total amount was about 7.310.173 item with average $9.5 \pm 2.7$ item $/ \mathrm{m}^{2}$ and total weight was about $241.759 \mathrm{~kg}$ with average $229.2 \pm 109.9 \mathrm{~g} / \mathrm{m}^{2}$. 
Table 1. Total of plastic debris per site (item/ $/ \mathrm{m}^{2}$ ).

\begin{tabular}{lccccccc}
\hline \multirow{2}{*}{ Type } & \multicolumn{7}{c}{ Site } \\
\cline { 2 - 8 } \multicolumn{1}{c}{1} & 2 & 3 & 4 & 5 & 6 & 7 \\
\hline Plastic drink bottle & 4.9 & 3.0 & 2.4 & 2.8 & 4.0 & 3.9 & 5.0 \\
Plastic cup & 3.7 & 4.7 & 5.5 & 3.6 & 6.0 & 4.3 & 3.2 \\
Rope \& fish-net & 0.3 & 0.3 & 0.4 & 0.2 & 0.6 & 0.3 & 0.7 \\
Gas matches & 0.9 & 0.2 & 0.4 & 0.3 & 0.7 & 0.3 & 0.4 \\
Basket & 0.0 & 0.0 & 0.0 & 0.0 & 0.1 & 0.0 & 0.0 \\
Bouy & 0.04 & 0.02 & 0.00 & 0.03 & 0.05 & 0.03 & 0.03 \\
Plastic packaging & 0.7 & 0.3 & 0.4 & 0.4 & 0.4 & 0.2 & 0.3 \\
Toothbrush & 0.1 & 0.0 & 0.0 & 0.0 & 0.0 & 0.0 & 0.0 \\
Plastic spoon & 0.1 & 0.0 & 0.0 & 0.0 & 0.0 & 0.0 & 0.0 \\
Syringe & 0.1 & 0.0 & 0.0 & 0.0 & 0.0 & 0.0 & 0.0 \\
\hline
\end{tabular}

Table 2. Weight of Plastic Debris per site $\left(\mathrm{g} / \mathrm{m}^{2}\right)$.

\begin{tabular}{lccccccc}
\hline \multirow{2}{*}{\multicolumn{1}{c}{ Type }} & \multicolumn{7}{c}{ Site } \\
\cline { 2 - 8 } \multicolumn{1}{c}{1} & 2 & 3 & 4 & 5 & 6 & 7 \\
\hline Plastic drink bottle & 128.9 & 71.6 & 70.5 & 52.1 & 114.3 & 83.0 & 100.2 \\
Plastic cup & 36.6 & 52.3 & 32.7 & 32.7 & 62.8 & 44.3 & 51.6 \\
Rope \& fish-net & 129.0 & 101.9 & 18.6 & 18.6 & 24.9 & 36.2 & 72.7 \\
Gas matches & 13.4 & 2.2 & 3.5 & 3.5 & 4.0 & 2.4 & 4.0 \\
Basket & 25.8 & 30.4 & 26.3 & 26.3 & 8.8 & 3.5 & 11.5 \\
Bouy & 18.0 & 6.4 & 0 & 0 & 16.0 & 6.2 & 14.3 \\
Plastic packaging & 11.7 & 2.0 & 2.7 & 2.7 & 3.1 & 7.8 & 8.1 \\
Toothbrush & 1.2 & 0 & 0 & 0 & 0.0 & 0 & 0 \\
Plastic spoon & 0.3 & 0.2 & 0 & 0 & 0.0 & 1.4 & 0 \\
Syringe & 0.4 & 0 & 0 & 0 & 0.0 & 0 & 0 \\
\hline
\end{tabular}

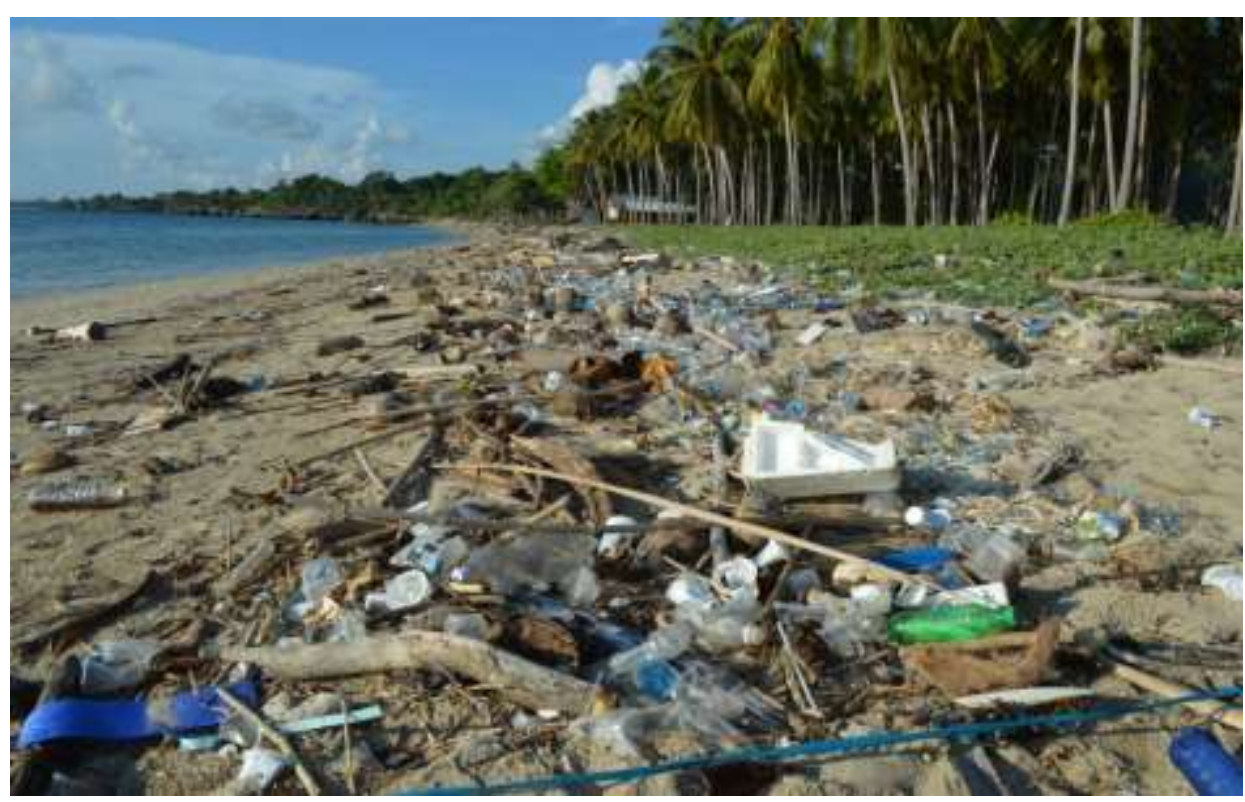

Figure 2. Plastic debris stranded on the beach. 


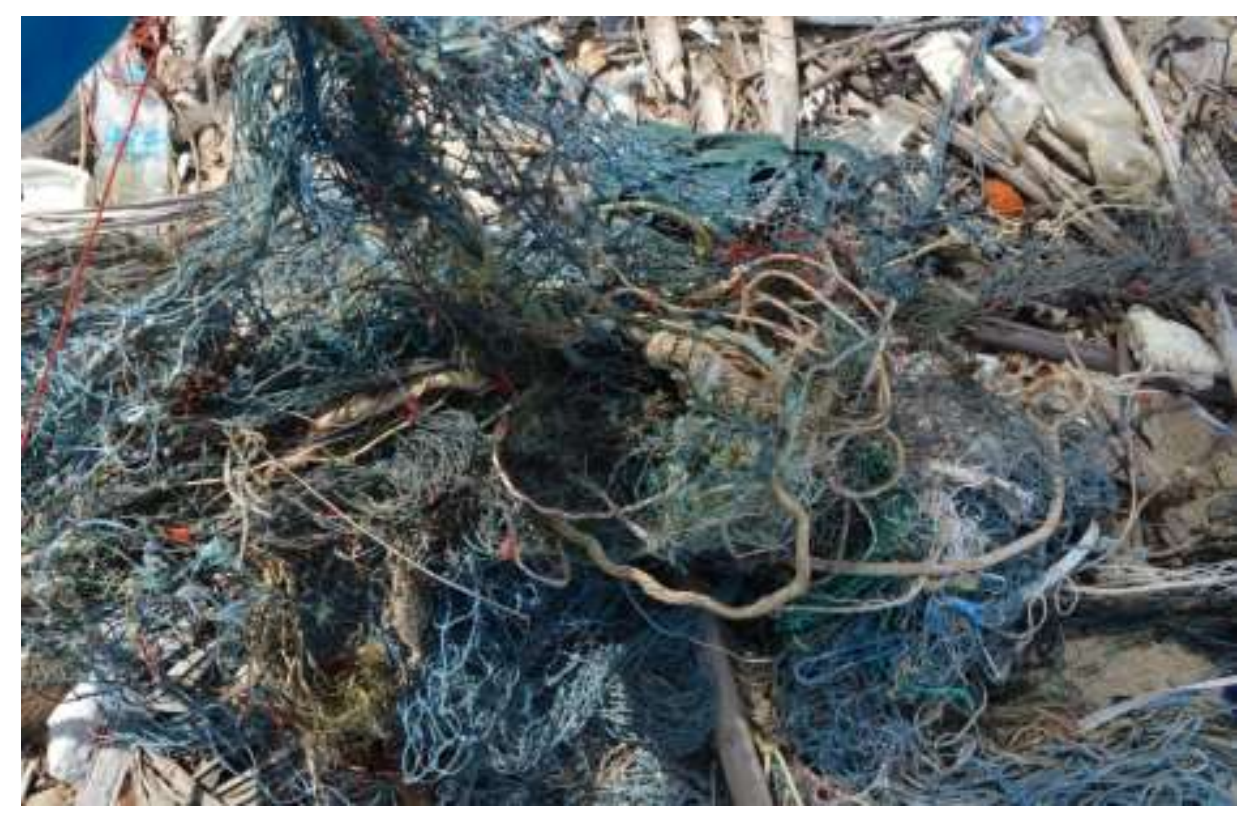

Figure 3. Broken fish-net abandoned on the beach.

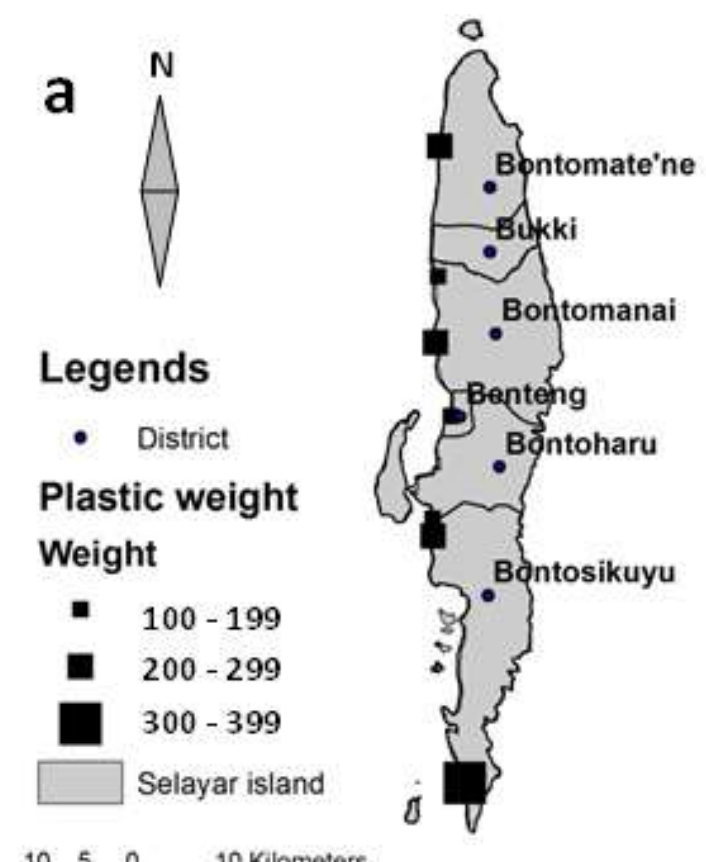

$1050 \quad 10$ Kilometers

a Weight of Plastic debris $\left(\mathrm{g} / \mathrm{m}^{2}\right)$

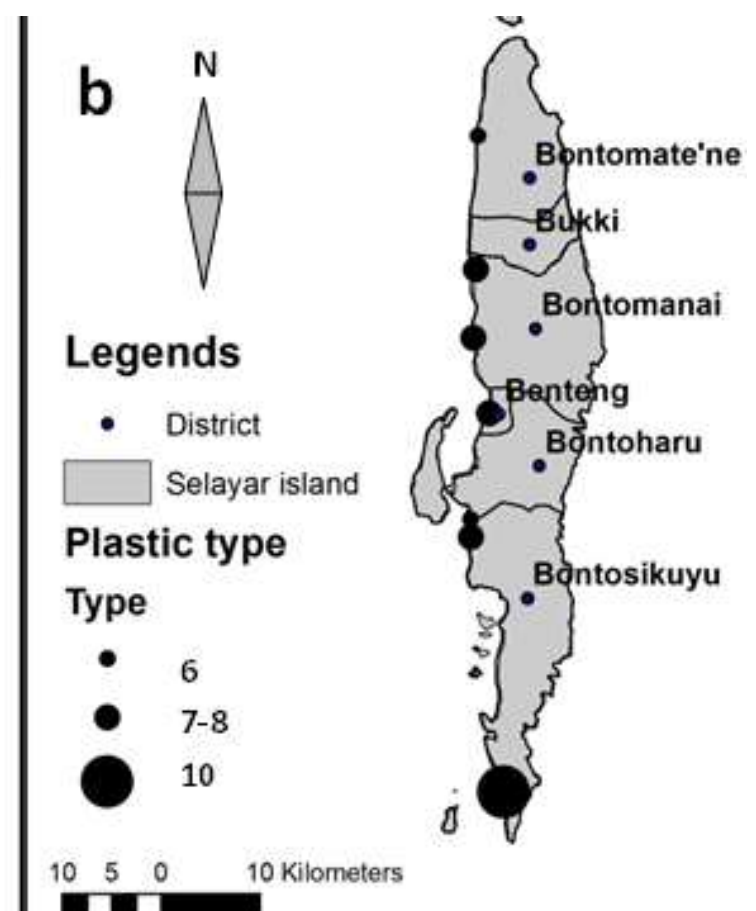

b Types of Plastic debris (type).

Figure 4. Map of plastic debris spreads.

The spread of plastic debris along the west coast of Selayar island and deposited on the beach, west coast has a length of 108,59 $\mathrm{km}$, plastic litter covered $70,78 \mathrm{~km}$ or $65,18 \%$ of coastline. Based on observations and calculations at site 1 of 10 type of plastic debris, which was dominated plastic bottle (Figure 4b) and a highest average weight of plastic debris at site 1 was about $300-400$ $\mathrm{g} / \mathrm{m}^{2}$ (Figure $4 \mathrm{a}$ ). 


\subsection{Plastic Debris Impact on Social}

Social appraisals for plastic debris quite varied, it is because some locals found that the deposited debris is a natural phenomenon that commonly occurs annually. To know the community assessment conducted by interviewing randomly at each site point of observation and categorized by Likert. Based on 7 observation site points with 110 respondents were mostly local who settled and lived on the west coast of Selayar island, presented in Figure 5. Aesthetics beach interrupted by marine debris were piled up, the plastic debris is also disturbing tourism activities such as swimming or enjoy the beach view. Local activities were interrupted by plastic debris as beach covered by plastic and marine debris, which is access to the shore and fishing activities. Fishing gears often disrupted and damaged by plastic debris, thus reducing catches. Marine litter provides the aesthetic impact on the coastal environment and the economic impact of various industries that depend on coastal environmental and sea (Bergmann, 2015).

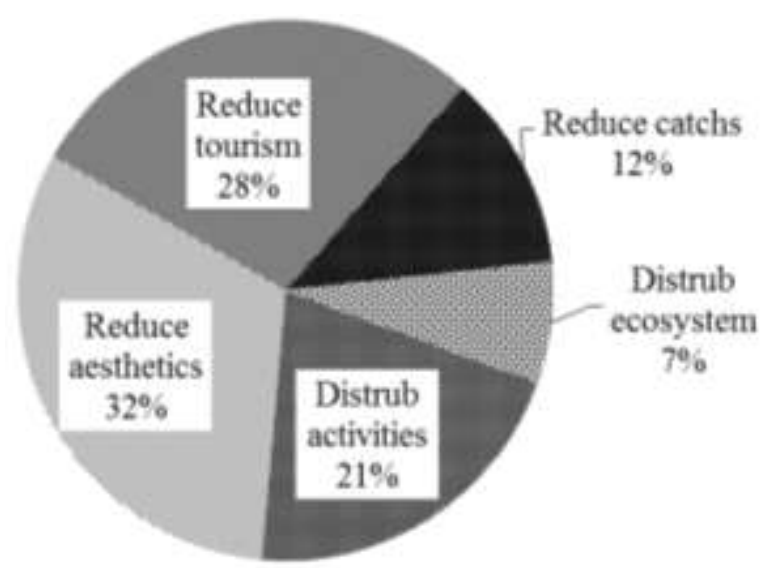

Figure 5. Social impact of plastic debris.

Some type of are collected, utilized and sold by locals. Thick and heavy plastics are valuable, while plastics lightweight plastics such as mineral water bottle or plastic cups has no economic value and unmanaged while there were in large number, its can be potential benefit if it managed properly. Plastic waste collectors only receive a thick plastic due to the cost of transport from Makassar to Selayar island. The collectors in Selayar island also brought commodity crops to Makassar for efficient transport costs and improve benefits. The collector bought plastic debris only as a side benefit.

\subsection{Plastic Debris to Economy}

The Majority of fishermen on Selayar island is a side job, most of the population relying on the farming as the main livelihood (BPS, 2015). Many fishermen come from small island around the Selayar island such as Tinabo, Pasimasunggu, Taka Bonerate and other islands. On the Selayar island boats and ships activities are very high because Selayar is the capital district of Selayar islands, thus becoming berths, fishing spot, transporting, docking and transaction from Makassar or other islands.

Floating plastic debris disturbing even damaging part of ship as propeller of ship, engine cooling system and other damage that requires repair and maintenance cost higher. Fishing gear also affected and require high costs. Based on calculation of loss cost of boat and fishing gear by plastic debris, presented on Table 3 and Table 4.

Losses of cost by boats and fishing gears (Table 3 and Table 4) derived from the number of vessels and fishing gears were operating on the west coast of Selayar island (>300 nautical miles) and information from local fishermen, shipowners, and ship docking worker.

Number of frequency entangled of vessel propeller and reapiring costs from surveyed vessel that anchored on west coast of Selayar during west monsoon, information of entangled propeller was asked to helmsman, vessel crews and mechanic crews. Informations about loss of fixed fishing gear such as frequency of cleaning, fixing net, fixing frame, replacing bouy, anchor, rope, canopy and other parts were asked to gear owner, gear crews and other locals that worked on fixed fishing gear. 
Table 3. Table of impacted fishing vessel by plastic debris.

\begin{tabular}{lccc}
\hline \multicolumn{4}{c}{ Loss of Fishing-Vessel by Plastic Debris } \\
\hline \multicolumn{1}{c}{ District } & Small (<10 GT) & Moderate (10-30 GT) & Large (>30 GT) \\
\hline Bontosikuyu (unit) & 44 & 49 & 5 \\
Bontoharu (unit) & 59 & 77 & 9 \\
Benteng (unit) & 39 & 62 & 9 \\
Bontomanai (unit) & 15 & 45 & 10 \\
Bontomatene (unit) & 30 & 55 & 10 \\
\hline TOTAL & 187 & 288 & 37 \\
\hline $\begin{array}{l}\text { Amounts of vessel on west coast } \\
\text { (unit) }\end{array}$ & 47 & 130 & 0.25 \\
Frequency of entangled of vessel & 0.05 & 0.09 & 0.25 \\
propeller (unit) & 0.60 & 0.45 & 5.000 .000 \\
$\begin{array}{l}\text { Frequency of repairing (unit) } \\
\text { Cost of propeller repairing (Rp) }\end{array}$ & 500.000 & 2.000 .000 & 5.000 .000 \\
$\begin{array}{l}\text { Cost of other repairing (Rp) } \\
\text { Numbers of entangled of vessel }\end{array}$ & 500.000 & 1.000 .000 & 9 \\
propeller (unit) & 2 & 13 & 9 \\
Numbers of others & & & 46.762 .500 \\
repairing/cleaning (unit) & 28 & 58 & 46.762 .500 \\
Total cost propeller repairing (Rp) & 1.168 .750 & 25.920 .000 & 93.525 .000 \\
Total cost for others & 14.025 .000 & 58.320 .000 & \\
repairing/cleaning (Rp) & 1.5193 .750 & 84.240 .000 & \\
Total (Rp) & 192.958 .750 & & \\
Total Loss Rupiah (Rp) & & & \\
\hline
\end{tabular}

Table 4. Table of impacted fishing gear by plastic debris.

\begin{tabular}{|c|c|c|c|c|}
\hline \multicolumn{5}{|c|}{ Loss of Fishing Gear } \\
\hline District & $\begin{array}{l}\text { Fixed Lift-net } \\
(\text { Bagan })\end{array}$ & $\begin{array}{l}\text { Boat Lift-net } \\
\text { (Bagan Apung) }\end{array}$ & $\begin{array}{c}\text { Set-Net } \\
(\text { Sero })\end{array}$ & Fish Traps \\
\hline Bontosikuyu (unit) & 5 & 5 & 3 & 12 \\
\hline Bontoharu (unit) & 10 & 45 & 15 & 35 \\
\hline Benteng (unit) & 3 & 5 & - & - \\
\hline Bontomanai (unit) & 3 & 5 & 6 & - \\
\hline Bontomatene (unit) & 0 & 0 & 25 & - \\
\hline Total fishing gear (unit) & 21 & 60 & 49 & 47 \\
\hline $\begin{array}{l}\text { Amounts of fishing gear on west } \\
\text { coast (unit) }\end{array}$ & 13 & 36 & 39 & 28 \\
\hline $\begin{array}{l}\text { Impact and extra cleaning, net, } \\
\text { frame, buoy, anchor, etc (unit) }\end{array}$ & $45 \%$ & $30 \%$ & $80 \%$ & $45 \%$ \\
\hline $\begin{array}{l}\text { Number of affected by plastic } \\
\text { debris (unit) }\end{array}$ & 6 & 11 & 31 & 13 \\
\hline $\begin{array}{l}\text { Cost of repairing, fixing, cleaning } \\
\text { ( } 1 \text { to } 3 \text { million rupiah) }\end{array}$ & 17.010 .000 & 32.400 .000 & 94.080 .000 & 12.690 .000 \\
\hline Total Loss (rupiah) & & 156.180 .000 & & \\
\hline
\end{tabular}


The total loss of the vessels were about 193 million IDR and fishing gears were about 156 million IDR each year. Nets of fishing gear often damaged by plastic debris such as stuck on the set-net that fixed installed in tidal areas, so its very easy affected by sharp or large number of plastic debris. Set net also easy to uprooted because its used wood-stick frame and require high cost for repairing.

Several studies of loss due to plastic debris from fishing vessels or fishing gears, such as the British ship losses 1.245 to 3.283 million US dollars in 2008 (Lee, 2014), in 2008, 286 rescues of vessels with fouled propellers in United Kingdom waters were carried out at a cost of between $€ 830.000$ and $€ 2.189 .000$ (Watskins, 2015). Japan's loss 18,4 million US dollars for the ship in 1985 (Takehama, 1990). British losses for the fishing gear 12.000 to 67.500 US dollars in 2012 (Lee, 2014).

Plastic debris impacted all coastal activities such as marine organism, ecological processes, aesthetics problem, safety and health, decreasing number of tourism, ghost fishing, distrubing sea transportation. During west peroid there were no tourism activities on Selayar west coast because of marine litter. Abandoned, Lost or otherwise Discraded Fishing Gear/ ALDFG, fishing gear becomes ALDFG when the fisher loses all operational control of the equipment (Smolowitz et al., 1978). As control over fishing gear is lost, the selectivity and efficiency of the gear for the original target species may be altered, overall ghost fishing catches are probably very low compared to controlled fishing (Brown et al., 2005).

\section{CONCLUSION}

Plastic debris on Selayar island spread along $70.78 \mathrm{~km}$ or $65.14 \%$ of west coast, dominated by plastic wrapper from daily consumption. Plastic debris density average $9.5 \pm 2.7$ item $/ \mathrm{m}^{2}$ and weight was about $229.2 \pm 109.9 \mathrm{~g} / \mathrm{m}^{2}$. Socio-economic impact to local activities, marine tourism, sea-transportation, ghost fishing and economic loss of fisheries industry especially for fishermen about 349 million IDR each year.

\section{ACKNOWLEDGEMENT}

The authors are grateful to all colleague for participating in this research and contributed to collecting Marine Litter survey data, such as crew of Takabonerate National Park, The government of Selayar Islands and Marine Coastal Management of IPB students.

\section{REFERENCES}

Badan Penelitian dan Pengembangan Sumber Daya Laut dan Pesisir (Balitbang KP). 2016. Data Perairan Indonesia, http://p3sdlp.litbang.kkp.go.id/index. $\mathrm{php} /$ data/perairan-indonesia. [Retrieved on February 2016].

Badan Pusat Statistik (BPS). 2015. Statistik daerah kabupaten Kepulauan Selayar 2015. Badan Pusat Statistik Kabupaten Kepulauan Selayar. Makassar. 40hlm.

Bergmann, M., L. Gutow, and M. Klages. 2015. Marine anthropogenic litter. Springer international publishing AG Switzerland. Springer Science. Business Media. Gothenburg. 447p.

Brown, J., G. Macfadyen, T. Huntington, J. Magnus, and J. Tumilty, 2005. Ghost fishing by lost fishing gear. Final Report to DG Fisheries and Maritime Affairs of the European Commission. Fish/2004/20. Institute for European Environmental Policy/ Poseidon Aquatic Resource Mana-gement Ltd joint report. www.ieep. org.uk/assets /243/ghostfishing.pdf. [Retrieved on October 2016].

Choy, C. and D.J. razen. 2013. Plastic for dinner? Observations of frequent debris ingestion by pelagic predatory fishes from the central North Pacific. 
Marine Ecology Progress Series, 485:155-163.doi:10.3354/meps1032.

Derraik, J.G.B. 2002. The pollution of the marine environment by plastic debris: a review. Marine Pollution Bulletin, 44:842-852.

European Centre for Medium-Range Weather Forecasts (ECMWF). 2015. Surface current data, http://www. ecmwf.int/. [Retrieved on February 2016].

Jambeck, J.R., R. Geyer, C. Wilcox, T.R. Siegler, M. Perryman, A. Andrady, R. Narayan, and K.L. Law. 2015. Plastic Waste Inputs from Land into The Ocean. Marine Pollution. Science, 347:768-771.

Lambert, S. 2013. Environmental risk of polymers and their degradation Products. Disertation. Environment Department. University of York, Canada. 198p.

Lee, J. 2014. Economic valuation of marine litter and microplastic pollution in the marine enviroment: An initial assessment of the case of the United Kingdom. www.eftec.co.uk/lee-paper /download. [Retrieved on October 2016].

Lindgren, D. 2011. Form and Function of coastal Areas. Dissertation. Upsalla University. Sweden. 52p.

Lippiatt, S., S. Opfer, and C. Arthur. 2013. Marine Debris Monitoring and Assessment. NOAA Technical Memorandum NOS-ORandR-462005, http://marinedebris. noaa .gov/sites/ default/files/Lippiatt_et_al_2013.pdf.

[Retrieved on October 2016].

Moore, C. 2015. How much plastic is in the ocean? You tell me. Marine Pollution Bulletin, 92:1-3.

Sherman, P. and E. Sebille. 2016. Modeling marine surface microplastic transport to assess optimal removal locations. IOP Publishing. Environ. Res. Lett. 11-19pp. DOI:10.1088/1748-326/11/1 /014006.
Smolowitz, R.J. Corps, L.N. and Center, N.F. 1978. Lobster, Homarus americanus, trap design and ghost fishing. Mar. Fish. Rev. 40(5):2-8.

Takehama, S. 1990. Estimation of damages to fishing vssels caused by Marine Debris, Based on Insurance Statistics. Fishing Ground Enviroment Conservation Division. Fisheries Agency Japan. 792-808p.

Uneputty, P.A. and S.M. Evans. 1997. Accumulation of Beach Litter on Islands of the Pulau Seribu Archipelago, Indonesia. Marine Pollution Bulletin, 34(8):652-655.

Uneputty, P. and S.M. Evans. 1997b. The Impact of Plastic Debris on the Biota of Tidal Flats in Ambon Bay (Eastern Indonesia). Marine Environmental Research, 44(3):233-242

United Nations Environmental Programme (UNEP). 2005. Marine litter: An analytical overview. http://www. unep.org/regionalseas/marinelitter/pu blications/docs/anl_oview.pdf. [Retrieved on February 2016].

United Nations Environmental Programme (UNEP). 2009. Guidelines on survey and monitoring of marine litter. Regional Seas Reports and Studies No. 186 IOC Technical Series No. 83. www.unep.org/PDF/UNEP_2009_A NNUAL_REPORT. pdf. [Retrieved on February 2016].

Walalangi, J. 2012. Analisis komposisi sampah organik dan anorganik serta dampak terhadap lingkungan pesisir Kota Palu Sulawesi Tengah. Thesis. Bogor Agricultural University. 112p.

Watkins, E., P.T. Brink, S. Withana, K. Mutafoglu, J.P. Schweitzer, D. Russi, and M. Kettunen. 2015. Marine litter: Socio-Economic Study. Scoping report. Institute for European Environmental Policy. London, Brussels. 365-394p.

Williams, A.T. and S.L. Simmons. 1997. Estuarine litter at the river/beach 
interface in the Bristol Channel,
United Kingdom. J. of Coastal Research 13:1159-1165.

Willoughby, N.G., H. Sangkoyo, and B.O. Lakaseru. 1997. Beach litter: an increasing and changing problem for Indonesia. Elsevier. Marine Pollution Bulletin, 34:469-478.
Wyrtki. K. 1961. Scientific results of marine Investigations of the South China Sea and the Gulf of Thailand. $2^{\text {nd }}$ ed. Pergamon Press Ltd. California. 195p.

Diterima : 16 Maret 2017

Direview : 22 Februari 2017

Disetujui : 20 Mei 2017 